\title{
Designing the Information Educational Environment of the Studying Course for the Educational Process Management Using Cloud Services*
}

\author{
OleKSANDRA I. KARINTSEVA ${ }^{i}$, ANDRIY V. YeVDOKYMOV ${ }^{i i}$, \\ Alona V. YeVDokymovaii, MyKola O. KHARCHENKo ${ }^{i v}$, VikToria V. Dron ${ }^{v}$
}

The authoritative International Data Corporation (IDC) estimates that by 2023, global spending on public cloud services and infrastructure will be more than double, mainly due to the introduction of digital transformations. Globally, the cloud market is becoming a field of increasingly fierce competition between the world's leading IT corporations. Modern education is rapidly evolving due to teachers who in recent years have introduced cloud services in their professional activities. There was an urgent question about the formation of information and educational environment for cooperation, collaboration, communication and learning mobility. This study is devoted to the analysis of the methods peculiarities of designing the information and educational environment of the discipline with the help of GoogleServices. The authors reviewed Google Services for designing open and closed information and educational environments, which are free, so they can be actively used in the educational process. The advantages of open and closed information-educational environment of the discipline as environments for the organization and management of the educational process are described. In the study, the authors identified the following characteristics of the information and educational environment: openness (support for modern standards, Internet / Intranet technology); scalability (increasing the number of services provided in the environment; the amount of information that can be processed); expansion of databases and knowledge (does not lead to the need to reconfigure the system); integration (the ability to organize a single educational environment to expand the tasks associated with the development and design of educational and methodological support of the educational process); adaptability (dynamic adjustment to the needs of both a particular educational institution and an individual user).

Key words: cloud technologies, information educational environment, open and closed educational environment, Google-services, educational process management.

${ }^{i}$ Oleksandra I. Karintseva, Dr.Sc. (Economics), Professor, Department of Economics, Enterpreneurship and Business-Administration, Sumy State University;

${ }^{i i}$ Andriy V. Yevdokymov, C.Sc. (Economics), Associate Professor, Department of Economics, Enterpreneurship and Business-Administration, Sumy State University;

iii Alona V. Yevdokymova, C.Sc. (Technics), Seniour Lecturer, Department of Management, Sumy State University:

${ }^{i v}$ Mykola O. Kharchenko, C.Sc. (Economics), Associate Professor, Department of Economics, Enterpreneurship and Business-Administration, Sumy State University;

${ }^{v}$ Victoria V. Dron, student of Oleg Balatskyi Academic and Research Institute of Finance, Economics and Management, Sumy State University.

* The publication contains the results of research conducted within the framework of the scientific research work "Development of the Fundamental Bases of the Reproductive Mechanism of Socio-Economic Development during the Third Industrial Revolution” (№ 0118U003578).

(C) O. I. Karintseva, A. V. Yevdokymov, A. V. Yevdokymova, M. O. Kharchenko, V. V. Dron, 2020

https://doi.org/10.21272/mer.2020.89.07

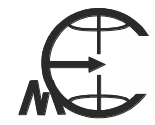


Introduction. In the twenty-first century, every economic field has undergone global changes. Many branches of science and entrepreneurships have lost their relevance, while vehicle has always been and will always be a priority in the economy, since without the normal functioning of transport, further development of the economic, sociocultural and financial spheres of the economy is impossible. Thus, the level of transport development is today a decisive factor in determining volumes of exports and imports, and as a result, it determines the GDP and citizens' living standards.

In 2018, the World Bank published an updated Logistics Performance Index (LPI) rating, in which Ukraine has risen by 14 positions comparison to 2016 (rating is published every second year). The rating is made up of five areas and the result is the level of road transport infrastructure development. The rating is an indication that road haulage in Ukraine has begun to develop and become a priority in recent years. Road transport in Ukraine carries $64 \%$ of cargo. Therefore, we believe that the study of road haulage is especially relevant today.

Problem statement. According to the forecasts of the leading consulting companies in the world, the rapid improvement and spread of cloud technologies (cloud computing) is one of those key trends now, in the next 5-8 years, they will significantly affect the global development of not only the IT industry, but also business, finance, and government, medicine, education and many other areas of human life [5]. A promising and cost-effective modernization choice and an optimal investment in future are considered within the conditions of accelerated development of ICT and another recession in the global economy, cloud technologies, which, for example, allow organizations and others to abandon the high costs of their own IT infrastructure in favour of obtaining all the necessary IT resources online.

It suffices to remark that according to the estimates of the reputable International Data Corporation (IDC), by 2023, global spending on public cloud services and infrastructure will be more than double, mainly due to the introduction of digital transformations. According to a market researcher, the average annual growth rate (CAGR) will be $22.3 \%$ - from 229 billion in 2019 to almost 500 billion in 2023 [13].

In the global dimension, the cloud technology market becomes a field of relentless competition between the world's leading IT corporations (Google, Yahoo, Amazon, Microsoft, Zoho, Cisco, Symantec, Fujitsu and many others).

Recently, world leaders in the information technology industry have been paying increasing attention to the educational sector, and this is not about traditional discounts on products and devices for educational institutions, but about independent specialized educational projects. In particular, the Ministry of Education and Science of Ukraine and Google recently signed an agreement to improve the digital skills of educators. Wilson White, the director of public policy and public relations at Google, stressed that digital skills are fundamental in the developing world. Google's priority is helping those who need these skills to improve. The company has successfully implemented many projects with the Ministry of Education and Science and is ready to move on in other directions.

According to the Law of Ukraine "On Education" (Article 41, Clause 3, Paragraphs 7-8), the system of providing quality education institutions with educational activities (internal quality assurance system) requires the availability of the necessary resources for the educational process organization, including for independent work of applicants and education and information systems for effective management of the educational institution [15], which in turn causes the rapid introduction of information technology, in particular, information systems to support the activities of organizational and training units in the process of educational process organization in educational institutions. 
Oleksandra I. Karintseva, Andriy V. Yevdokymov, Alona V. Yevdokymova, Mykola O. Kharchenko, viktoria V. Dron Designing the Information Educational Environment of the Studying Course for the Educational Process Management Using Cloud Services

The purpose of the article is to determine the content of the concept of "information educational environment of the studying course" for educational process management based on Google services.

Results of the research. A study of informatization and computerization processes in educational process management for a significant period has been studied by such scientists as Agranovych, B., Arzhanova, A., Glushchenko, O., Danylenko, L., Ielnikova, G., Kudas, N., Maslova, V., Pometun, O., Spivakovskyi, O., Tykhonov, A., Fedorova, Ia., by using cloud technologies Aleksanian, G., Bykov, V., Dziubenko A., Dziamulych, N., Kademii, M., Kobys', V., Kuzmynska, O., Lytvynova, S., Morse, N., Ognev'iuk, V., Popel', M., Rozhdestvenska, L., Rudenko, V., Sklater, N., Khevvit, K. Shyshkina, M. and others. The creation of an information educational environment has been the subject of several studies by such scientists as Bykov, V., Gurevych, R., Grygorieva, S., Zakharova, I., Sysoeva, S., Paniukova, S., Pozdniakova, S., Polat, E., Robert, I.

According to the researches of Bykov, V., Vagramenko, Ia., Zakharova, I., Mashbytsia, Iu., Polat, E., Robert, I., Sysoeva, S., Tykhomirov, O. and others, the significant potential is contained inappropriate ICT-based teaching methods, since they can provide individualized learning, adaptation to their abilities, possibilities and interests of the learners, development of their independence and creativity, access to new sources of educational information, use of computer modelling of the studied processes, objects, etc. Thus, it should be about creating and using the educational environment for teachers to manage the educational process. Therefore, we should talk about the creation and use of information educational environment by teachers to manage the educational process.

The implementation of Google services in the educational process was carried out by Balyk, N., Morse, N., Oleksiuk, V., Kalinina, L., Noskova, M., Spirin, O., Rozhdestvenska, L., Shyshkina, M. and Khrypun, V. The authors propose different approaches to understanding the nature and structure of the information educational environment. However, in all studies, the components of the information educational learning environment are divided into two categories: subjects and objects.

Students and teachers are the subjects of the information educational environment.

Teaching aids and educational activity tools, methods, material base, pedagogical process management, communication methods (organizational and managerial, explanatory and motivational, behavioural for an answer, technical, emotional) are the objects. Objects are those information carriers and educational activities that, being assimilated and transformed by the consciousness of subjects, are changed in the process of educational activity as an individual in a worldview, a system of values and meanings, beliefs, competencies, etc.

Work in the information educational environment changes the roles of subjects: the student is at the centre of training, including his motives, goals, his psychological characteristics. All methodological issues (the educational process organization, the use of techniques, means, etc.) are refracted through the prism of the student's personality: his needs, abilities, activity, intelligence.

Modern education experiences rapid development thanks to teachers who, over the past few years, have been introducing cloud services in their professional activities. There is an urgent question about the formation of an information educational environment for collaboration, cooperation, communication and educational mobility.

Yakimanska I. notes the more diverse the information educational environment, the more effective the process of management and training, considering the individual capabilities of 
each, his interests, inclinations, subjective experience that has been accumulated in teaching and real-life [6].

The resort to information and communication technologies significantly expands the composition and capabilities of many components of the information educational environment in the studying course. So, the sources of studying information in these conditions include databases and reference systems, electronic textbooks, encyclopedias, Internet resources, etc. Computer simulators can be considered to be educational activities tools and control programs can be deemed to be communication tools (local computer networks or the Internet).

The information educational environment in the studying course is a single information space of the studying course, provides integral support for its study, a complicated approach to the use of ICT in the educational process through project activities, interactive communication systems, testing and monitoring of knowledge and skills.

We distinguish the following characteristics of the educational environment:

- openness (support of modern standards, Internet/Intranet technologies);

- scalability (increase in the number of services in the background; the amount of information that can be processed); system);

- expansion of databases and knowledge (does not lead to the need to reconfigure the

- integrity (the ability to organize a single educational environment to extend the tasks associated with the development and design of educational and methodological support of the educational process);

- adaptability (dynamic adjustment to the needs of both a particular educational institution and an individual user).

The use of Google services (see Figure 1) in the educational process primarily addresses the problem of ensuring equal access for students and teachers to quality scholarly resources, both during and after class.

Google services are free so that they can be actively used in the educational process.

The use of these services in the educational process offers the following advantages:

- To use Google services, there is no need to buy a Windows operating system. To start using the services, an Internet connection, a browser, and any freely distributed operating system or mobile device are enough.

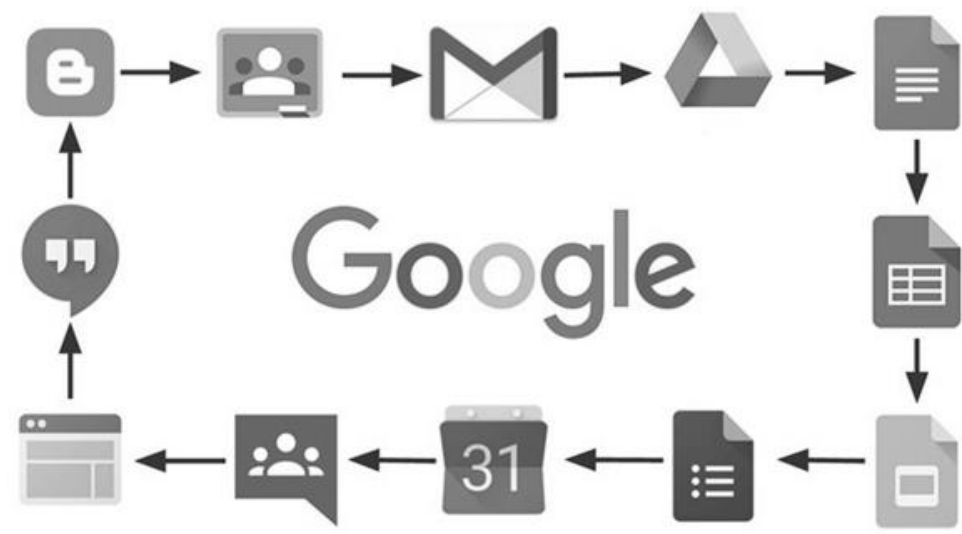

Figure 1. Google services to build an educational environment 
Oleksandra I. Karintseva, Andriy V. Yevdokymov, Alona V. Yevdokymova, Mykola O. Kharchenko, viktoria V. Dron Designing the Information Educational Environment of the Studying Course for the Educational Process Management Using Cloud Services

- Access to materials can be obtained both from the educational establishment and from home.

- Collaboration with students online.

- Ability to check the progress of work interactively.

- We are monitoring the progress of work without the need to distract the student from it.

Let us consider the possibility of using Google services for designing an open and closed information educational environment in the studying course.

The formation of an open information educational environment in the studying course can be done using the Google Site. Having your website opens up great opportunities for promoting specific ideas in all areas, including education. And even if you do not know anything about web design and programming, using Google Site, you can create your product in just a couple of hours. At the same time, your site will have a modern and easy to read design, adapted for mobile phones and tablets. It will be a kind of open area for communication with colleagues, students and everyone interested.

After creating the site, you can proceed to the stuffing of it. The page editor is no more complicated than a regular text editor, so if you worked, for example, in Google Docs, then everything is simple and familiar to you. In the same way, you type text, links, change formatting, paste tables, pictures, and so on. Also, the Insert menu has an additional section that is responsible for interacting with other Google services. It allows the teacher to insert, for example, a Carousel module, Google Drive, Google Calendar, a YouTube clip, a Google Maps map, a Picasa image, and other sources. It can also invite other users to collaborate on the site, control their access to materials. Many different services that can be used in the educational process offer a Google Account for authorization, and some of them can even be automatically stored on Google Drive, such as Google, a service for creating mental maps.

Google Drive is a Google-owned data warehouse, allows users to store their data on cloud servers and share them with other users on the Internet. Google offers all users the initial 15 GB of online storage space. Google Drive includes Google Docs, Sheets, and Slides, an office suite that lets you edit documents, spreadsheets, presentations, drawings, forms, and many others. Everything is done in the same way as when working with Google Docs document on a computer using MS Word. The Google Sheet spreadsheet can be edited, set filters, printed, and other, that is, as in MS Excel. As of October 2019, there were 240,000,000 monthly active users.

The Google Drive service opens an extremely wide field of opportunities in the educational process for teachers (preparation for classes, technology use in the Classroom, differentiated training, creating an educational environment, extracurricular work), methodical work (work in educational and methodical associations, educational districts, creative groups, self-education), work with parents, the public, and the like. Placing a compendium of lectures, instruction cards for practical work, presentations, and other materials on the site is not the demands of times, but a required element of the educational process of a modern teacher.

Websites can be used for quests, coverage of student-led projects.

This resource also contains information about the activities of the teacher: publications, useful links, methodical materials, practical advice to colleagues, achievements.

Google Classroom is a closed information educational environment, and it holds a special place.

Google Classroom is a unique Google app because it is designed specifically for educational purposes. It combines Google Drive for creating and sharing tasks, Google Docs, Sheets and Slides for writing, Gmail for communication and Google Calendar for scheduling. 
Students can be invited to the class via a secret code. Each class creates a separate folder on the Google drive of the corresponding Google Drive user, where students can submit work that the teacher evaluates.

Mobile applications are available on iOS and Android, allowing users to take photos and attach them to tasks, share files from other apps and have offline access to information. The teacher can track the progress of each student, and after evaluating his work, he can return it along with private comments.

The Classroom is convenient for both a teacher and a student, since the service provides users with a universal working device, has a comfortable, intuitive interface and the capabilities necessary for participants in the educational process.

The key features of the Classroom are the following:

1. Setting up a Classroom. Each class creates its access code, which participants of the educational process used to join the training course. Alternatively, the teacher can send out invitations to his training course by sending e-mails to a group of students; they open the received message and press the "Join" button, and after that, they automatically become members of the Classroom.

2. Integration with Google Drive. When a teacher uses Google Classroom, the Classroom folder is created automatically on his or her Google Drive. Students also create a Classroom folder with subfolders for each class to which they join.

3. Various opportunities to create and distribute tasks. The Classroom interface has four tabs "Flow", "Tasks", "People", and "Ratings" on top. The tab "Flow" is a blog page that displays all of your posted messages and is open to communication. The tab "Tasks" provides for the creation of various types of messages: tasks, tasks with a test, question, material, use of existing messages; The point "Subject" allows you to structure all messages by topic. All types of messages make it possible to use links to files of any kind with Google Drive, an external link and a link to a video from YouTube. Thus, conditions are provided for students to access educational material (presentations, lectures, demonstrations, interactive tasks, testing, additional literature and video lessons). The "People" tab reflects all participants in the course and allows the teacher to send an e-mail to the student and withdraw it if necessary.

When creating a task in the form of Google-Docs, the platform will create and distribute individual copies of the document for each member of the Classroom with a name such as "last name, first name" - "document name". It makes it possible to give tasks to restore records, insert missed tasks, and tasks that require a detailed answer.

It is also possible to provide access for simultaneous work on one document to several users. Collaboration expands learning opportunities, students can help each other, and this approach contributes to the development of communicative competence, the manifestation of leadership qualities (work in groups).

4. Time management. When creating tasks, the teacher can indicate the deadline. When a student submits tasks before the deadline, "View" mode appears on his document, which allows the teacher to check the work. After verification, the teacher can return the tasks to the student for revision. It automatically switches to "Editing" mode, and the student continues to work on the document. Also, it is possible to schedule the task publication for the desired date and time using the "Schedule" option.

5. Task monitoring and evaluation. All tasks can be monitored simultaneously and control work on a separate task in several classes at once. The evaluation can be done manually or automatically. The rating system can be adapted to any number of points (automatically 100 points). After evaluation, using the Return button, the grade is sent to the e-mail of each class 
Oleksandra I. Karintseva, Andriy V. Yevdokymov, Alona V. Yevdokymova, Mykola O. Kharchenko, viktoria V. Dron Designing the Information Educational Environment of the Studying Course for the Educational Process Management Using Cloud Services

participant, although you can change the grade if necessary. It is also possible to export all course grades to a spreadsheet.

6. Communication in the Classroom. Due to the combination of the capabilities of the "Flow" service and commenting on tasks in the Classroom, teachers and students always keep in touch and monitor the verification of each assignment.

Conclusions and prospects of further research. One of the main tasks of education today is to prepare students for the quick perception and processing a body of information, equip them with modern means and technologies of work, develop their information culture, life competencies and, in particular, information competence.

The most important criterion for determining the function of the information educational environment in the studying course is convenience (which includes safety) and the possibility of collective work. The ease of use, free-of-charge basis and high availability of Google Classroom and other Google services, which the digital giant Google constantly updates and improves, enables teachers to manage and organize ICT support for conventional forms of learning, as well as for blended, distance and individual learning and to use forms of group work widely. Education is not limited to an educational institution. The materials are placed in an open or closed information educational environment, and students can view at home to repeat learned material, or to understand the topic better if something was not clear during the study. After mastery of the material, each student will be able to choose the adoption rate, processing and absorption of information. We believe that this will contribute to increase motivation for learning and better mastering of learned material.

To create students' informational competence, the teacher should himself possess such competence, understand the role that he can play in shaping the student's personality and in the educational process management.

Creating a particular website for the teacher is a rational decision because it is possible to organize educational content and the lack of third party information. Having his resource and using Google services, the teacher can systematize the knowledge he has, find new information, share it with his students promptly, and thereby increase the efficiency of the educational process management.

\section{References}

1. Bykov, V. Yu. (2008). Modeli orhanizatsiynykh system vidkrytoii osvity: monohrafiia [Models of organizational systems of open education: a monograph]. K. : Atika, 684 p. [in Ukrainian].

2. Bykov, V. Yu. (2010). Vidkryte navchal'ne seredovyshche ta suchasni merezhni instrumenty system vidkrytoii osvity [Open Learning Environment and Modern Networking Tools of Open Education Systems]. Naukovyi chasopys NPU imeni M. P. Drahomanova - Scientific journal of NPU names M. P. Drahomanov. Retrieved from http://nbuv.gov.ua/UJRN/Nchnpu_2_2010_9_4.

3. Dron, V. V. (2019). Servisy Google v upravlins'kii diial'nosti [Google services in management]. Materialy III Vseukrayins'koii konferentsiii “Sotsial'no-pedahohichni osnovy rozvytku osobystosti v suchasnykh umovakh komunikatsiii: dosvid, problemy, perspektyvy" [Collection of Proceedings of the Third All-Ukrainian Conference "Socio-pedagogical foundations of personality development in modern conditions of communication: experience, problems, prospects"]. Dnipro : Vydavnytstvo "ZHURFOND", $452 \mathrm{p}$.

4. Dron, V. V. (2019). Proektuvannia informatsiino-osvitnioho seredovyshcha $\mathrm{z}$ dystsyplin pryrodnychoho napriamu [Design of information and educational environment in the studying courses of natural science]. Materialy VII mizhnarodnoii naukovo-praktychnoii internet-konferentsiii "Suchasnyy rukh nauky" [Proceedings of the VII International Scientific and Practical Internet Conference "The Modern Movement of Science"]. Dnipro, 1977 p.

5. Fast Forward Five Years: Cloud Becomes the Standard. (n.d.). Retrieved from 
https://www.symantec.com/content/en/us/enterprise/white_papers/esg-protecting-a-cloudierfuture.en-us.pdf

6. Hurevych, R. S. (Ed.). (2013). Informatsiini tekhnolohiii navchannia: innovatsiinyi pidkhid: navchal'nyi posibnyk [Information Technologies of Learning: An Innovative Approach: A Tutorial]. Vinnytsia : Planer, $499 \mathrm{p}$.

7. Kademiya, M. Yu., Koziar, M. M., Tkachenko, T. V., Shevchenko, L. S. (2008). Informatsiine osvitnie seredovyshche suchasnoho navchal'noho zakladu [Informational educational environment of the modern educational institution]. Lviv : SPOLOKH, $186 \mathrm{p}$.

8. Kalinina, L. M., Noskova, M. V. (2013). Google-servisy dlia vchytelia. Pershi kroky novachka: Navch. posib. [Google-services for the teacher. Beginner's First Steps: Study guide]. Lviv : ZUKTS.

9. Kremen, V. H., Bykov, V. Yu. (2013). Katehoriii "prostir" i "seredovyshche": osoblyvosti model'noho podannya ta osvitn'oho zastosuvannia [Categories "space" and "environment": features of model representation and educational application]. Teoriia i praktyka upravlinnia sotsial'nymy systemamy [The theory and practice of social systems management], 2, 3-16.

10. Lytvynova, S. G. (2015). Modeliuvannia i intehratsiia servisiv khmaro oriientovanoho navchal'noho seredovyshcha: monohrafiia [Modeling and integration of cloud-oriented learning environment services: monograph]. K. : Comprynt, 163 p.

11. Lytvynova, S. G. (Ed.). (2016). Proektuvannia khmaro oriyentovanoho navchal'noho seredovyshcha zahal'noosvitn'oho navchal'noho zakladu: monohrafiia [Designing a cloud-oriented educational environment of a comprehensive educational institution: monograph]. Kyiv : Comprynt, $354 \mathrm{p}$.

12. Smulson, M. L. (Ed.). (2015). Intelektual'nyi rozvytok doroslykh u virtual'nomu osvitn'omu prostori. monohrafiia [Adult intellectual development in the virtual educational space: a monograph]. K. : Ped. dumka, $221 \mathrm{p}$.

13. Svitovi vytraty na khmarni servisy dosiahnut' 500 mlrd dolariv v 2023 rotsi [Worldwide cloud service costs will reach $\$ 500$ billion in 2023]. (n.d.). Retrieved from https://www.denovo.biz/blog/svitovi-vitrati-na-hmarni-servisi-dosyagnut-500-mlrd-dolariv-62.

14. Voronkin, O. S. (2012). "Khmarni" obchyslennia iak osnova formuvannia personal'nykh navchal'nykh seredovyshch [Cloud computing as a basis for the formation of personal learning environments]. Zbirnyk naukovykh prats': materialy druhoii mizhnarodnoii naukovo-praktychnoii konferentsiii FOSSLviv [Collection of Scientific Papers: Proceedings of the Second FOSSLviv International Scientific and Practical Conference]. Lviv, 143-146.

15. Zakon Ukraiiny "Pro osvitu" vid 16.01.2020 No 2145-VIII [Law of Ukraine "On Education" from 16.01.2020 No 2145-VIII]. Retrieved from https://zakon.rada.gov.ua/laws/show/2145-19.

Manuscript received 12 August 2020

Проектирование информационно-образовательной среды дисциплины для управления образовательным процессом с помощью облачных сервисов

\section{АЛЕКСАНДРА ИвАНОВНА КАРИНЦЕВА*, АНДРЕЙ ВАЛЕРЬЕВИч ЕВДОКИМОВ ${ }^{* *}$, АЛЁНА ВИКТОРОВНА ЕВДОКИМОВА $* * *$, НИКОЛАЙ АЛЕКСЕЕВИЧ ХАРЧЕНКО $* * * *$, ВИКТОРИЯ ВАСИЛЬЕВНА ДРОНЬ ${ }^{* * * * *}$}

* доктор экономических наук, доиент, заведующая кафедры экономики, предпринимательства и бизнес-администрирования Сумского государственного университета, ул. Р.-Корсакова, 2, г. Сумы, 40007, Украина, тел.: 00-380-542-332223, e-mail: karintseva@econ.sumdu.edu.ua 
Oleksandra I. Karintseva, Andriy V. Yevdokymov, Alona V. Yevdokymova, Mykola O. Kharchenko, viktoria V. Dron Designing the Information Educational Environment of the Studying Course for the Educational Process

Management Using Cloud Services

***андидат экономических наук, дочент, доцент кафедры экономики, предпринимательства и бизнес-администрирования Сумского государственного университета, ул. Р.-Корсакова, 2, г. Сумыл, 40007, Украина, тел.: 00-380-542-332223,e-mail: a.evdokimov@econ.sumdu.edu.ua

**** кандидат технических наук, стариий преподаватель кафедры управления Сумского государственного университета, ,

ул. Р.-Корсакова, 2, г. Сумыл, 40007, Украина,

тел.:00-380-542-687878,e-mail: a.yevdokymova@management.sumdu.edu.ua

***** кандидат экономических наук, доцент, доцент кафедры экономики, предпринимательства и бизнес-администрирования Сумского государственного университета, ул. Р.-Корсакова, 2, г. Сумы, 40007, Украина,

тел.:00-380-542-332223,e-mail:m.kharchenko@econ.sumdu.edu.ua

***** студентка учебно-научного института финансов, экономики и менеджмента им. Олега Балацкого Сумского государственного университета, ул. Р.-Корсакова, 2, г. Сумы, 40007, Украина,

По подсчетам авторитетной International Data Corporation (IDC), к 2023 году объем мировых расходов на публичные облачные сервисы и инфраструктуру увеличится более чем вдвое, в основном за счет внедрения цифровых преобразований. В глобальном измерении рынок облачных технологий становится полем более жесткой конкуренции между ведущими мировыми IT-корпорациями. Современное образование испытывает стремительное развитие благодаря педагогическим работникам, которые в течение последних лет внедряют облачные сервисы в своей профессиональной деятельности. Встал насущный вопрос о формировании информационно-образовательной среды для сотрудничества, кооперации, коммуникации и учебной мобильности. Это исследование посвящено анализу особенностей способов проектирования информационно-образовательной среды дисциплины с помощью Googleсервисов. Авторами рассмотрены Сервисы Google для проектирования открытой и закрытой информационно-образовательной среды, являются бесплатными, поэтому их активно можно использовать в образовательном процессе. Описываются преимущества открытой и закрытой информационно-образовательной среды дисциплины как среды для организации и управления образовательным процессом. В исследовании авторами выделено следующие характеристики информационно-образовательной среды: открытость (поддержка современных стандартов, технологии Интернет / Интранет) масштабируемость (увеличение количества сервисов в среде; объема информации, которая может обрабатываться); расширение баз данных и знаний (не влечет к необходимости перенастраивать систему); интегрированность (возможность организовать единое образовательное среду для расширения задач, связанных с разработкой и проектированием учебно-методического обеспечения образовательного процесса); адаптированность (динамическая настройка под нужды как конкретного учебного заведения, так и отдельного пользователя).

Ключевые слова: облачные технологии, информационная образовательная среда, открытая и закрытая образовательная среда, Google-сервисы, управление учебным процессом.

\section{Mechanism of Economic Regulation, 2020, No 3, 87-97} ISSN 1726-8699 (print)

Проектування інформаційно-освітнього середовища дисципліни для управління освітнім процесом із допомогою хмарних сервісів

ОЛЕКСАНДРА ІВАНІВНА КАРІНЦЕВА*, 


\title{
АНДРІй ВАЛЕРІйОвИч СВДОКИМОв**, АЛЬОНА ВІкТоРІвНА СвдОКИМОвА $* * *$, МИКОЛА ОЛЕКСЕЙОВИЧ ХАРЧЕНКО ${ }^{* * * *}$, ВІКТоРІя ВАСИЛІВНА ДРОНЬ ${ }^{* * * * *}$
}

\author{
* доктор економічних наук, доцент, завідувачка кафедри економіки, підприємництва та бізнес- \\ адміністрування Сумського державного університету, \\ вул. Р.-Корсакова, 2, м. Суми, 40007, Україна, \\ тел.: 00-380-542-332223, e-mail: karintseva@econ.sumdu.edu.ua \\ ** кандидат економічних наук, доцент, доцент кафедри економіки, підприсмництва та бізнес- \\ адміністрування Сумського державного університету, \\ вул. Р.-Корсакова, 2, м. Суми, 40007, Україна, \\ тел.: 00-380-542-332223, e-mail: a.evdokimov@econ.sumdu.edu.ua \\ **** кандидат технічних наук, старший викладач кафедри управління Сумського державного \\ університету, \\ вул. Р.-Корсакова, 2, м. Суми, 40007, Україна, \\ тел.: 00-380-542-687878, e-mail: a.yevdokymova@management.sumdu.edu.ua \\ ***** кандидат економічних наук, доцент, доцент кафедри економіки, підприємництва та бізнес- \\ адміністрування Сумського державного університету, \\ вул. Р.-Корсакова, 2, м. Суми, 40007, Україна, \\ тел.: 00-380-542-332223, e-mail: m.kharchenko@econ.sumdu.edu.ua \\ ***** студентка навчально-наукового інституту фінансів, економіки і менеджменту ім. Олега \\ Балацького Сумського державного університету, \\ вул. Р.-Корсакова, 2, м. Суми, 40007, Украӥна,
}

За підрахунками авторитетної International Data Corporation (IDC), до 2023 року об'єм світових витрат на публічні хмарні сервіси та інфраструктуру збільшиться більше ніж вдвічі, переважно за рахунок впровадження цифрових перетворень. У глобальному вимірі ринок хмарних технологій стає полем чимдалі жорсткішої конкуренції між провідними світовими ІТ-корпораціями. Сучасна освіта зазнає стрімкого розвитку завдяки педагогічним працівникам, які протягом останніх років впроваджують хмарні сервіси в своїй професійній діяльності. Постало нагальне питання про формування інформаційно-освітнього середовища для співпраці, кооперації, комунікації та навчальної мобільності. Це дослідження присвячене аналізу особливостей способів проектування інформаційно-освітнього середовища дисципліни за допомогою Google-сервісів. Авторами розглянуто Сервіси Google для проектування відкритого та закритого інформаційно-освітнього середовища, що є безкоштовними, тому їх активно можна використовувати в освітньому процесі. Описуються переваги відкритого та закритого інформаційно-освітнього середовища дисципліни як середовищ для організації та управління освітнім процесом. У дослідженні авторами виділено наступні характеристики інформаційно-освітнього середовища: відкритість (підтримка сучасних стандартів, технології Інтернет/Інтранет); масштабованість (збільшення кількості сервісів, що надаються в середовищі; об'єму інформації, яка може оброблятися); розширення баз даних і знань (не призводить до необхідності переналагоджувати систему); інтегрованість (можливість організувати єдине освітнє середовище для розширення задач, пов'язаних з розробкою та проектуванням навчально-методичного забезпечення освітнього процесу); адаптованість (динамічне налагодження під потреби як конкретного навчального закладу, так і окремого користувача).

Ключові слова: хмарні технології, інформаційне освітнє середовище, відкрите та закрите освітнє середовище, сервіси Google, управління навчальним процесом. 
Oleksandra I. Karintseva, Andriy V. Yevdokymov, Alona V. Yevdokymova, Mykola O. Kharchenko, viktoria V. Dron Designing the Information Educational Environment of the Studying Course for the Educational Process Management Using Cloud Services

JEL коди: I21, O14, L86.

Figures: 1 ; References: 15

Language of the article: English

Лimepamypa

1. Биков, В.Ю. Відкрите навчальне середовище та сучасні мережні інструменти систем відкритої освіти. [Електронний ресурс] / Науковий часопис НПУ імені М. П. Драгоманова. Режим доступу : http://nbuv.gov.ua/UJRN/Nchnpu_2_2010_9_4.

2. Биков, В. Ю. Моделі організаційних систем відкритої освіти: монографія / В. Ю. Биков. - К. : Атіка, 2008. -684 c.

3. Дронь, В. В. Проектування інформаційно-освітнього середовища 3 дисциплін природничого напряму / В. В. Дронь // Матеріали VII міжнародної науково-практичної інтернет-конференції «Сучасний рух науки». 6-7 червня 2019 р. - Дніпро, 2019. - 1977 с.

4. Дронь, В.В. Сервіси Google в управлінській діяльності. Матеріали III Всеукраїнської конференції «Соціально-педагогічні основи розвитку особистості в сучасних умовах комунікації: досвід, проблеми, перспективи» / голова редкол. Удалова О. А., члени ред. кол. Буянова Г. В., Ватагіна В. В., ्̈вженко Ю. В., Похресник А. К. Дніпро : Видавництво «ЖУРФОНД», 2019. - $452 \mathrm{c}$.

5. Fast Forward Five Years: Cloud Becomes the Standard [Електронний ресурс] / Symantec. Режим доступу : https://www.symantec.com/content/en/us/enterprise/white_papers/esg-protectinga-cloudier-future.en-us.pdf.

6. Гуревич, Р. С. Інформаційні технології навчання: інноваційний підхід: навчальний посібник / Р. С. Гуревич, М. Ю. Кадемія, Л. С. Шевченко; за ред. Р. С. Гуревича. - Вінниця : Планер, 2013. - $499 \mathrm{c}$.

7. Кадемія, М. Ю. Інформаційне освітнє середовище сучасного навчального закладу / М. Ю. Кадемія, М. М. Козяр, Т. В. Ткаченко, Л. С. Шевченко. - Львів : СПОЛОХ, 2008. - 186 с.

8. Калініна, Л. М. Google-сервіси для вчителя. Перші кроки новачка: навч. посіб. / Л. М. Калініна, М. В. Носкова. - Львів : ЗУКЦ, 2013.

9. Кремень, В. Г. Категорії «Простір» і «середовище»: особливості модельного подання та освітнього застосування / В. Г. Кремень, В. Ю. Биков // Теорія і практика управління соціальними системами. 2013. - № 2. - С. 3-16.

10. Литвинова, С.Г. Проектування хмароорієнтованого навчального середовища загальноосвітнього навчального закладу : монографія / С. Г. Литвинова. - Київ. : ЦП «Компринт», 2016. - $354 \mathrm{c.}$

11. Копняк, $Н$. Моделювання й інтеграція сервісів хмаро орієнтованого навчального середовища : монографія / Н. Копняк, Г. Корицька, С. Литвинова, Ю. Носенко та ін. // за заг. ред. С. Г. Литвинової. - К. : Компринт, 2015. - 163 с.

12. Смульсон Ю. М. Інтелектуальний розвиток дорослих у віртуальному освітньому просторі : монографія / М. Л. Смульсон, Ю.М.Лотоцька, М. М. Назар, П.П.Дітюк, І. Г. КоваленкоКобилянська та ін. // за ред. М. Л. Смульсон. - К. : Пед. думка, 2015. - 221 с.

13. Світові витрати на хмарні сервіси досягнуть 500 млрд доларів в 2023 році. [Електронний peсурс]. - Режим доступу : https://www.de-novo.biz/blog/svitovi-vitrati-na-hmarni-servisidosyagnut-500-mlrd-dolariv-62.

14. Воронкін, О.С. «Хмарні» обчислення як основа формування персональних навчальних середовищ // Збірник наукових праць: матеріали другої міжнародної науково-практичної конференції FOSSLviv 2012. Львів, 26-28 квітня 2012 р. - Львів, 2012. - С. 143-146.

15. Закон України «Про освіту» від 16.01.2020 № 2145-VIII. [Електронний ресурс] / Офіційний веб-сайт Верховної Ради України. - Режим доступу : https://zakon.rada.gov.ua/laws/show/214519. 